УДК 811.161.1

\title{
ОЦЕНОЧНАЯ ДИНАМИКА КОНЦЕПТУАЛЬНОГО ПОЛЯ ТУРЦИЯ В РУССКОМ МЕДИА-ДИСКУРСЕ 2010-2017-х ГОДОВ
}

\author{
МУРАТ АКСОЙ
}

аспирант

Киевский национальный лингвистический университет kafrosukr@gmail.com

В статье проанализировано лингвальное наполнение концептуального поля ТУРЦИЯ в российской картине мира. Обосновано структуру концепта, определены его ядро и периферия, а также особенности взаимодействия с другими концептами. Показано динамику изменений в оценочном освещении указанного концептуального поля в российском медийном дискурсе 2010 - 2017-х годов.

Ключевые слова: оценочная динамика, концепт, концептуальное поле ТУРЦИЯ, медиа-дискурс, концептуализация, субконцепты.

\section{ОЦІННА ДИНАМІКА КОНЦЕПТУАЛЬНОГО ПОЛЯ ТУРЕЧЧИНА В РОСІЙСЬКОМУ МЕДІА-ДИСКУРСІ 2010-2017-х РОКІВ}

Мурат АКСОЙ

аспірант

Київський національний лінгвістичний університет kafrosukr@gmail.com

Робота присвячена вивченню особливостей мовної реалізації концептуального поля ТУРЕЧЧИНА в російському медіа-дискурсі. Актуальність дослідження визначається необхідністю виявлення механізмів, які б пояснювали способи вербалізації актуальних концептів сучасності.

Метою статті $\epsilon$ розробка структури концептуального поля ТУРЕЧЧИНА та ілюстрація його оцінної динаміки, з'ясованої на основі вивчення способів вербалізації цього поняття в російських 3МІ 2010-2017-х років.

Методи. Дослідження виконано із застосуванням методів концептуального аналізу та компонентного аналізу.

Результати. Аналіз оцінної динаміки концептуального поля ТУРЕЧЧИНА в російському медіа-дискурсі дав підстави структурувати це утворення, виділивши в ньому ядерну та периферійну зони. Також показано його взаємоперетин з іншими концептуальними полями. Оцінну динаміку поля встановлено на основі оцінних висловлювань у текстах ЗМІ.

Висновки. Концептуальне поле ТУРЕЧЧИНА становить складну систему, засновану на взаємодії центрального поняття ТУРЕЧЧИНА з іншими поняттями поля АГРЕСИВНОСТI, а саме з концептами КОНФЛІКТ, ВОРОЖІСТЬ, ПОЛІТИКА, ВІЙНА та ін. Залежно від того, який 3 них починає домінувати, змінюються оцінки як самого концепта ТУРЕЧЧИНА, так і його субконцептів.

Ключові слова: оцінна динаміка, концепт, концептуальне поле ТУРЕЧЧИНА, медіа-дискурс, концептуалізація, субконцепти.

EVALUATIVE DYNAMICS OF CONCEPTUAL FIELD TURKEY

IN RUSSIAN MEDIA DISCOURSE OF THE 2010TH

Murat AKSOJ

Graduate student

Kyiv National Linguistic University kafrosukr@gmail.com 
Introduction. The paper focuses on the problem of linguistic realisation of the conceptual field TURKEY in Russian media discourse. Topicality of the research is determined by the necessity of revealing the mechanism, which would explain the ways of verbalization of the dynamics of conceptual field TURKEY taking place in cognitive structure of the text.

Purpose. The paper aims at working out the structure of conceptual field TURKEY and illustrating its estimated dynamics grounded on the ways of this concept verbalization in Russian media texts of 2010th.

Methods. The investigation is made provided the method of conceptual analysis and the methods of componential analysis as well.

Results. Analyzing the evaluative dynamics of conceptual field TURKEY in Russian media discourse gave the reason for structuring this concept, describing its nuclear and ways of its interconnection with other concepts. Thus, the evaluative dynamics of this conceptual field in Russian media discourse of 2010th is presented in the paper.

Conclusions. Dynamics of conceptual field TURKEY is a complex system, which is grounded on the interconnection of nuclear concept TURKEY with other concepts of AGRESSION, for instance: CONFLICT, ANMITY, POLITICS, WAR, etc. Depended on the concept which may dominate at this or that situation, evaluative meaning of the concept TURKEY or its subconcepts may also change.

Keywords: evaluative dynamics, concept, conceptual field TURKEY, media discourse, conceptualization, subconcepts

Постановка проблемы. Концептуализация является важной частью когнитивной деятельности человека, поскольку концепты, образующиеся в результате названного процесса, упорядочивают информацию об объектах окружающей действительности. Очень важно фиксировать изменения в оценочной интерпретации концептов.

Актуальность данного исследования определяется потребностью выявления динамики концептуального поля ТУРЦИЯ, находящей свою реализацию в когнитивной структуре текста, путем анализа русскоязычного медийного дискурса 2010-х годов.

Анализ последних исследований и публикаций. Проблема изучения концепта ТУРЦИЯ как составной части концепта СТРАНА в русскоязычной картине мира находится в русле важнейших лингвистических исследований, так как правильное восприятие особенностей той или иной страны важно как с точки зрения лингвистики, так и с позиций межнациональной коммуникации. В современной русистике исследуются концепты РОССИЯ, АМЕРИКА, ГЕРМАНИЯ, ЕВРОПА (например, работы О. А. Гришиной (2004), Р. Д. Керимова (2013), О. А. Куданкиной (2005), О. Г. Орловой (2013), М. В. Пименовой (2011) и некоторых других авторов), однако концепт ТУРЦИЯ в настоящее время не изучен, несмотря на актуальность исследования данного направления в связи с популярностью отдыха в этой стране.

Цель исследования - выявить структурную организацию концептуального поля ТУРЦИЯ на основе его вербализации в русском медийном дискурсе 2010-х годов.

Изложение основного материала исследования. В современной лингвистической литературе много внимания уделяют изучению и сравнению концептосфер родственных и неродственных языков. Концептосферу считают основным источником формирования концептов, “сферой мысли” (Стернин, 2002, с. 47). Используя язык в любой сфере, люди актуализируют те или иные концепты, которые, в свою очередь, отражают мировоззрение, ценности, опыт, идеалы, чувства говорящих. В связи с этим показательно определение А. Вежбицкой (2001), которая считает, что концепт - это “объект из мира "Идеальное”, имеющий имя и отражающий культурно обусловленное представление человека о мире “Действительность” (с. 23).

Отношения между культурными концептами и их значениями достаточно сложны, поэтому когнитивная лингвистика и лингвокультурология сосредоточиваются на изучении соотношения языкового значения и культурного смысла. Для современной лингвистики “идея о первичности 
содержания и вторичности выражения стала основополагающей” (Снитко, 1999, с. 31), и в связи с этим в современных исследованиях уделяется большое внимание прежде всего изучению концептов и интерпретации их содержания.

Исследование особенностей концептуализации предполагает изучение не отдельных концептов, а всей совокупности связей - деривативных, ассоциативных, синонимических и антонимических, в которых находится концепт. Актуализуемые на основе всех названых связей лексемы составляют концептуальное поле. Это весьма сложное, структурированное образование, отражающее в диахронии и синхронии некоторый фрагмент действительности.

Концептуальному полю присущ ряд онтологических признаков, определяющих его организацию в языке и в тексте: 1) его ядерный концепт и конституенты тесно взаимодействуют между собой; 2) поле можно исследовать с точки зрения синхронии и диахронии; 3) поле отражает традицию и специфику национального концепта; 4) имеет общекультурный и ассоциативный фон. Из этого следует, что образование концептуального поля связано не только с мыслительной деятельностью носителей языка, но и с их культурой, традициями, историей, менталитетом.

Концептуальное поле моделируют на основании анализа языковых единиц. При определении его структуры учитывают мотивирующие признаки слова, которые непосредственно связаны с историей слова и его функционированием. Очень важно отметить образные признаки концепта, которые актуализируются вследствие разной сочетаемости слов. Безусловно, при структуризации поля принимают во внимание понятийные отношения между конституантами. Поле демонстрирует и ценностные признаки, которые так или иначе отражены в языковых значениях, коннотации лексем. По мнению ученых, концептуальное поле обладает и “функциональным и символическим признаками, раскрывающими сакральный характер того или иного концепта” (Словарь русского языка XVIII в., 1984, с. 294-295). Таким образом, концептуальное поле обладает множеством информации и очень красочно представляет языковую картину мира как структурированный фрагмент.

Рассмотрим особенности строения концептуального поля ТУРЦИЯ в русском медийном дискурсе в динамике 2010-2017-х годов, ибо тексты средств массовой информации репрезентируют наиболее актуальные оценки обществом того или иного объекта.

Мы считаем, что концепт ТУРЦИЯ нужно интерпретировать как кластерный концепт, который объединяет такие субконцепты, как ТУРКИ, ТУРОК, ТУРЧАНКА и некоторые другие. Как признак кластерного концепта рассматривается также возможность отнесения его к разным концептосферам. Нам представляется, что концепт ТУРЦИЯ в русской языковой картине мира пересекается с концептами СТРАНА, ГОСУДАРСТВО, ЗАГРАНИЦА, ВОСТОК и некоторыми “другими” (А. Н. Баранов и Д. О. Добровольский (2008) разводят термины государство и страна, отмечая, что для первого наиболее важна идея власти, а для второго - идея территории).

При изучении кластерных концептов важно не ограничиваться анализом дефиниций объективирующего концепт слова в лексикографических источниках. Очень ценной оказывается информация о концепте, полученная от носителей языка или из масс-медиа. Именно таким образом можно установить, с какими когнитивными областями пересекается исследуемый кластерный концепт, а также выделить наиболее точный перечень его субконцептов и определить закономерности их комбинаторики.

Восприятие Турции русскими в 2010-м году и в 2017-м году - нередко разное, оценка тоже менялась под влиянием политических событий. В частности, констатируем, что после сбитого самолета РФ в 2015-м году в концептуальное поле ТУРЦИЯ вплетаются концепты АГРЕССИЯ, ВОЙНА. ПОЛИТИКА, КОНФЛИКТ

Положение у русских в Туричи сейчас тяжелое. ... Радикализм довольно популярен: те турки, которые всегда были настроены против русскоязычного населения, сейчас еще больше активизировались. После таких событий они чувствуют себя особенно сильньли, ненависть сочится отовсюду (https://lenta.ru/articles/2015/11/30/rusturk/). 
Выделим структурные составляющие враждебности, чуждости:

1. Агрессивность турок.

“Украина и Туриия угрожают Крыму. НАТО сформирует в Черном море мощную военноморскую флотилию” (Независимая газета).

2. Политические амбиции.

"Туриия под прикрытием размытой формулировки "очистка района от террористических элементов" не только преследует миротворческие цели, но и удовлетворяет собственные политические амбици" (Газета.ру)

3. Опасный отдых.

Кроме того, можно отметить и освещение других событий в Турции в негативной коннотации:

В туреикой Анталии туристический автобус сорвался с 50-метровой скаль, об этом сообщает местный канал Haberturk.

По данным канала, в автобусе ехали 27 пассажиров - иностранных туристов. Национальность туристов не уточняется. Больше читайте здесь: https://ru.tsn.ua/svit/v-turciiavtobus-s-turistami-sorvalsya-so-skaly-smi-soobschayut-o-pogibshih-i-ranenyh-931950.html

СМИ: российский турист утонул в Туриии. В Аланье при купании утонул российский турист, 68-летний Николай Кудинов, сообщает Life со ссылкой на туреикие СМИ. Указывается, что тело погибщего в настоящее время направлено на экспертизу. (http://www.mk.ru/incident/ 2017/08/27/smi-rossiyskiy-turist-utonul-v-turcii.html)

Туреикие СМИ сообщили о ранении российского парашютиста. Москва. 24 сентября. INTERFAX.RU - Российский парашютист получил серьезные травмы, упав с высоты в 70 метров 23 сентября 2017, сообщает агентство “Анадолу”. Молодой человек прыгал с парашютом в районе Фетхие провинции Мугла... (http://www.interfax.ru/world/580321).

Приведенные примеры свидетельствуют о формировании в русской прессе негативного имиджа Турции как туристического государства, в котором русским отдыхающим может быть небезопасно, некомфортно, неспокойно.

При этом русские Интернет-ресурсы отмечают, что отношение к Турции в 2017 году изменилось не в лучшую сторону не только в россиян, но и в граждан других стан (http://turkey-is.ru/novosti/imidzh-turtsii/), то есть негативная оценка экстраполируется и на более широкий круг участков оценки, хотя конкретных примеров того, как оценивают Турцию граждане других стран, авторы не приводят.

Журналисты обращают внимание читателей на то, что Турция переживает не самый простой период своего развития в плане экономики, внутренней и внешней политики, безопасности и так далее. Интересно, как интерпретируют русские обозреватели перспективы Турции на международной арене. Некоторые из них оценивают новый слоган турецкой рекламной кампании “Turkey Discover the Potential”, то есть: “Турция открой (для себя её) потенциал”, как “очень правильный” (http://turkey-is.ru/novosti/imidzh-turtsii/). Весьма эффективным считают стратегическое решение привлечь в рекламу глав крупнейших зарубежных корпораций, которые ведут в Турции бизнес. В рекламных роликах их представлено в качестве “друзей Турции”. Очень важно, что, кроме глав турецких отделений Самсунга и Форда, в рекламном проекте фигурирует руководитель российского Сбербанка Герман Греф, который заявляет, что “Сбербанк не планирует продавать свой бизнес в Турции, перспективы его развития при наблюдающемся устойчивом экономическом росте в этой стране хорошие" (http://turkey-is.ru/novosti/imidzh-turtsii/). Такое заявление свидетельствует о наметившемся позитивном векторе отношений Турции и России.

Выводы и перспективы дальнейших исследований. Концептуальное поле ТУРЦИЯ представляет собой сложную систему, основанную на взаимодействии центрального концепта ТУРЦИЯ с другими концептами поля АГРЕССИВНОСТИ, а именно с конщептами КОНФЛИКТ, ВРАЖДЕБНОСТЬ, ПОЛИТИКА, ВОЙНА и др. В зависимости от того, какой из них начинает доминировать, меняются оценки как самого концепта ТУРЦИЯ, так и его субконцептов. 
Русский медиа-дискурс 2010-2017 гг. отражает разные оценки концепта ТУРЦИЯ в русском обществе. Динамика оценивания в большой мере обусловлена политическими обстоятельствами. В перспективе считаем важным исследовать оценочную составляющую проанализированного концептуального поля на материале других видов дискурса.

\section{ЛИТЕРАТУРА}

Баранов, А. Н. и Добровольский, Д. О. (2008). Аспекты теории фразеологии. Москва: Знак. Вежбицкая, А. (2001). Лексикография и концептуальный анализ. Москва: Языки русской культуры. Гришина, О. А. (2004). Актуализаџия кониепта АМЕРИКА в современном русском языке: на материале публииистических текстов. (Дис. канд. филол. наук). Кемерово.

Евгеньева, А. П. (Ред.). (1981). Словарь русского языка. (Т. 1). Москва: Рус. яз.

Керимов, Р. Д. (2013). Лингвокогнитивные аспекты изучения немецкой политической метафоры. Языковая картина мира. Гуманитарный вектор. 4 (36), 155-164.

Куданкина, О. А. (2005). Актуализаџия конџепта ГЕРМАНИЯ в российской публиџистике. (Дис. канд. филол. наук). Архангельск.

Ожегов, С. И. и Шведова, Н. Ю. (1999). Толковый словарь русского языка. Москва: Азбуковник. Орлова, О. Г. (2013). Дискурсивная теория стереотипа. (Автореф. дис. докт. филол. наук). Кемерово.

Пименова, М. В. (2011). Концептуальные исследования и национальная ментальность. Языковая картина мира. Гуманитарный вектор. 4 (28). 126-132.

Снитко, Т. Н. (1999). Предельные понятия в Западной и Восточной лингвокультурах. Пятигорск: Пятиг. гос. лингв. ун-т.

Сорокин, Ю. С. (Ред.). (1984). Словарь русского языка XVIII в. (Вып. 1.) Ленинград: Наука, Ленингр. отд-ние.

Стернин, И. А. (2002). Коммуникативное и когнитивное сознание. Слюбовью к языку. (с. 44-51). Воронеж: Воронеж. гос. ун-т.

\section{REFERENCES}

Baranov, A. N. i Dobrovol'skij, D. O. (2008). Aspekty teorii frazeologii. Moskva: Znak.

Vezhbitskaia, A. (2001). Leksikohrafiia i kontseptual'nyj analiz. Moskva: Yazyki russkoj kul'tury.

Hrishina, O. A. (2004). Aktualizatsiia kontsepta AMERIKA v sovremennom russkom iazyke: na materiale publitsisticheskikh tekstov. (Dis. kand. filol. nauk). Kemerovo.

Evgen'eva, A. P. (Red.). (1981). Slovar' russkogo iazyka. (T. 1). Moskva: Rus. iaz.

Kerimov, R. D. (2013). Lingvokognitivnyie aspekty izucheniia nemetskoj politicheskoj metafory. Yazykovaia kartina mira. Gumanitarnyj vektor. 4 (36), 155-164.

Kudankina, O. A. (2005). Aktualizatsiia kontsepta HERMANIIA v rossijskoj publitsistike. (Dis. kand. filol. nauk). Arkhanhel'sk.

Ozhegov, S. Y. i Shvedova, N. Yu. (1999). Tolkovyj slovar' russkogo iazyka. Moskva: Azbukovnik.

Orlova, O. H. (2013). Diskursivnaia teoriia stereotipa. (Avtoref. dis. dokt. filol. nauk). Kemerovo.

Pimenova, M. V. (2011). Kontseptual'nyie issledovaniia i natsional'naia mental'nost'. Yazykovaia kartina mira. Humanitarnyj vektor. 4 (28). 126-132.

Snitko, T. N. (1999). Predel'nyie poniatiia v Zapadnoj i Vostochnoj lingvokul'turakh. Piatigorsk: Piatig. gos. lingv. un-t.

Sorokin, Yu. S. (Red.). (1984). Slovar' russkogo iazyka XVIII v. (Vyp. 1.) Leningrad: Nauka, Leningr. otd-niie.

Sternin, Y. A. (2002). Kommunikativnoie i kognitivnoie soznaniie. S liubov'iu k iazyku. (s. 44-51). Voronezh: Voronezh. gos. un-t. 